\title{
Peter C. White (ed.): Crime scene to court: The essentials of forensic science, 3rd edition
}

\author{
Royal Society of Chemistry Publishing 2010, ISBN 978-1-84755-882-4
}

\author{
Claas T. Buschmann
}

Accepted: 23 February 2011/Published online: 26 April 2011

(C) Springer Science+Business Media, LLC 2011

The 3rd edition of "Crime Scene to Court", published by the Royal Society of Chemistry, continues to give general readers a fascinating and readily understandable account into the complex field of forensic science. The editor, Professor Peter C. White, has a broad background and wide experience in forensic science, teaching, research and practice. Having worked with the Metropolitan Police Forensic Science Laboratory in London and the Forensic Science Unit at the University of Strathclyde/UK, he was appointed director of the unit but left in 2003 to become a professor of Science at the University of Lincoln/UK. In 2006, he was appointed a Fellow of the Forensic Science Society. He has over 60 published papers, several book chapters and eight patents to his name. Since his early retirement in 2009, he runs his own forensic and analytical research consultancy. "Crime Scene to Court" was his inspiration and he edited both previous editions of the book. Although Professor White's research at the University mainly centred on the development of Raman spectroscopic techniques for ultratrace detection of solutes of forensic interest, the book-with excellent contributions from 23 specialised practitioners and recognised experts in their profession-covers the whole field of the discipline: It comprises 569 pages organized into 17 well-written and well-structured chapters (Forensic Practice; The Crime Scene; Forensic Ecology; Forensic Entomology; Trace and Contact Evidence; Marks and Impressions; Bloodstain Pattern Analysis; Forensic Examination of Documents;

C. T. Buschmann ( $\square)$

University Medical Centre Charité-University of Berlin Institute of Legal Medicine and Forensic Sciences, Turmstr. 21, Building N, 10559 Berlin, Germany

e-mail: claas.buschmann@charite.de

URL: http://remed.charite.de
Computer Based Media; Fire Investigation; Explosions; Firearms; Drugs of Abuse; Forensic Toxicology; Analysis of Body Fluids; Forensic Archaeology and Anthropology; Presentation of Expert Forensic Evidence) and is enriched with black and white photographs. It may be worthwhile considering adding colored photographs to forthcoming editions.

The 3rd edition has been thoroughly up-dated to reflect the advances in technology and the introduction of new methods and quality standards, with three chapters on forensic ecology, forensic entomology, and forensic archaeology and anthropology being added. The book covers the main areas of an investigation where forensic science is practiced: the crime scene, laboratory and court, including details of how crime scene and forensic examinations are conducted in the United Kingdom, the principles of crime scene investigations and the importance of this work in an investigation, courtroom procedures and the role of the expert witness. Cases are presented to illustrate why and how examinations are performed to generate forensic evidence. The book is written in an accessible style and each chapter contains a bibliography for those wishing to delve deeper into the subject. Ideal for those studying forensic science or law, the book is intended primarily for teaching and training purposes. However, anyone with a role in an investigation will find this text an excellent source of information: The book is enjoyable and delightful to read, and the topics can easily be grasped and appreciated even by non-expert readers. The reference list is up-to-date and a valuable tool for gathering further information.

To sum up, the book gives a unique and valuable account of the challenges faced in forensic medicine. It will serve as a readable resource for all of those who have an interest in forensic investigations and would like a clear, concise description of their background. 